University of California, Hastings College of the Law UC Hastings Scholarship Repository

Faculty Scholarship

1998

\title{
An Opportunity Not to be Missed: The Future of Comparative Law in the United States
}

Ugo Mattei

UC Hastings College of the Law, matteiu@uchastings.edu

Follow this and additional works at: http://repository.uchastings.edu/faculty_scholarship

Part of the Comparative and Foreign Law Commons, and the Estates and Trusts Commons

\section{Recommended Citation}

Ugo Mattei, An Opportunity Not to be Missed: The Future of Comparative Law in the United States, 46 Am. J. Comp. L. 709 (1998). Available at: http://repository.uchastings.edu/faculty_scholarship/527

This Article is brought to you for free and open access by UC Hastings Scholarship Repository. It has been accepted for inclusion in Faculty Scholarship by an authorized administrator of UC Hastings Scholarship Repository. For more information, please contact marcusc@uchastings.edu. 


\section{Faculty Publications \\ UC Hastings College of the Law Library}

Author: Ugo Mattei

Source: $\quad$ American Journal of Comparative Law

Citation: $\quad 46$ Am. J. Comp. L. 709 (1998).

Title: $\quad$ An Opportunity Not to be Missed: The Future of Comparative Law in the United States

Originally published in AMERICAN JOURNAL OF COMPARATIVE LAW. This article is reprinted with permission from AMERICAN JOURNAL OF COMPARATIVE LAW and Law School, Univ. of Michigan. 
UGO MATTEI

\section{An Opportunity Not to Be Missed: The Future of Comparative Law in the United States}

In this paper I will argue that the fate of comparative law will be determined by its ability to function as a connecting field between law and other social sciences. I will further argue that there is no future for comparative law if its future is linked to the so-called globalization of the law.

In recent years it has become fashionable to talk about the globalization of the law. A number of eminent law schools led by New York University have made clear their commitment to a global law program. In addition, a sizeable number of conferences focusing on international and comparative law have been organized, and a symposium issue of the Journal of Legal Education was devoted to the topic of globalization, ${ }^{1}$ as was the 1998 AALS meeting in San Francisco. In view of this trend, the question arises: What is the future of comparative law in the global law school?

The seemingly obvious answer is that comparative law will have a brilliant future in this new institutional environment. After all, comparative law scholars, since the birth of their discipline early in our century, have been claiming that the legal system does not end at the borders of the nation state. They have warned against parochialism, national positivism, state-centrism, and all the other sins that they detect in their provincial law school colleagues. Moreover, comparative law scholars are the only ones who have invested in preparing for the collapse of the nation state and the subsequent reversion to a period, much like the time of the ius commune in Europe, when the nationality of a lawyer does not matter and the law has its force not ratione imperii but, once again, imperio rationis. Rather than stemming from the State, the authority of law would flow from its intrinsic character regardless of which jurisdiction produced the law.

Ugo Matter is Alfred and Hanna Fromm Professor of Intemational and Comparative Law, University of California, Hastings. Professore Ordinario di Diritto Civile, Universitá di Torino. Previous drafts of this paper were delivered and discussed at two conferences: Comparative Law in The United States. Quo Vadis? at the University of Michigan Law School in 1996 and at the University of California, Hastings in 1997.

1. See Symposium on Globalization, 46 J. Legal Educ. 311 (1996). 
Indeed, it seems that we are finally reaching that period. ${ }^{2}$ Scholars from the social sciences have now declared that the nation state is, if not dead, at least in serious decline. International political scientist Susan Strange has argued that the power in the world has become diffused and that if one looks only at the nation state, one will overlook most of the important places in which social decision-making occurs. Strange suggests that among the beneficiaries of the "diffusion of power" after the retreat of the state will be the telecoms, insurance companies, the Big Six accountants, the mafias, the international organizations, and the big cartels of private protectionism. ${ }^{3}$ Anthropologist Laura Nader has made a similar point when looking at (among other things) the structure of the multinational corporation in order to detect the relationships of power that really matter in world society today. ${ }^{4} \mathrm{~A}$ few lawyers in the United States have arrived at the same conclusion. A recent symposium issue of the Cardozo Law Review was devoted to "The Decline of the Nation State" and a number of writers have entered the de profundis for the most successful political organization humankind has invented on its long path to civilization. ${ }^{5}$

If the enemy of comparative law is the nation state, its decline should present a great opportunity for our discipline. We will finally emerge from our marginal status in the legal curriculum and seize a central role everywhere, not just in a few law schools in this country. An abundance of job openings in the academic market will entice large numbers of young, ambitious and bright potential legal scholars to devote their energies to becoming comparative lawyers. In a few years, comparative law will occupy a prominent position in mainstream teaching and research. Following the course set by Law \& Economics, Critical Legal Studies, Legal Feminism, and Critical Race Theory, Comparative Law will finally become "cutting edge stuff." Everyone in the United States will read the American Journal of Comparative Law as avidly as it is read in Europe. The generation of

2. See Towards Universal Law. Trends in National European and International Lawmaking (Nils Jareborg ed., 1995) with writings stressing this point by such leaders in the field as Hein Kötz, James Gordley, Mireille Delmas-Marty, and Arthur Hartkamp.

3. See Susan Strange, The Retreat of the State. The Diffusion of Power in the World Economy (1996).

4. See, most recently, Nader, "The Phantom Factor: Impact of the Cold War on Anthropology," in The Cold War and the University. Toward an Intellectual History of the Post War Years (Noam Chomsky ed., 1997); Nader \& Grande, "Current Illusions and Delusions About Conflict Management," in African Traditional Conflict Medicine (I. William Zartman ed., 1998).

5. See Symposium, "The Decline of the Nation State and Its Effect on Constitutional and International Economic Law," 18 Cardozo L.R. 903 (1996). 
post-World War II refugees (whose contributions to our discipline are beyond frontal criticism 6 ), will be replaced.

This wonderland remains in the distant future. There is no rising star in the American legal academic profession who is a comparative lawyer by training; most tenured comparative law professors of the younger generation are foreigners. As far as I know, even NYU, with their global law school, has no full-time comparative law scholar on the faculty. The same is true at Stanford, Columbia, the University of Chicago, Cornell and other less well-known institutions.

One might well ask why. The answers vary. To begin with, it might be that my analysis is wrong - that the full-time professional comparative law scholar I envision is an obsolete figure in the global world, that the refugee scholars were not replaced simply because the work they were proposing was no longer needed. Perhaps American law absorbed the minimum amount of civil law necessary to survive and develop and domestic developments are now self-sufficient. Another possibility is that, while the American legal culture is desperately in need of replacing such towering figures, it has not happened because it is difficult to do so or, perhaps, because other disciplines, more familiar or less demanding, are functioning as good substitutes for comparative law. The first possibility, that there is no need to replace the post war refugee comparative law scholars, is simply absurd. If American law faculties were packed with experts on African Law, Chinese Law, Japanese Law, and Latin American Law the argument that the role of the post-war refugees has become obsolete might have some merit. ${ }^{7}$ But this is by no means the case. Considering the function of cross-fertilization that comparative scholarship has carried on in the United States obsolete - even limited as it was between the United States and Western Europe - means to have no grasp of the pathetic episodes of reinvention of the wheel into which so many modern American legal theorists fall. Even more important, the shortage of professional, general comparative law scholars means that many schools are not able to offer a general introduction to comparative law through which students develop the methodological awareness of being parochial. Without this awareness there are no incentives to move beyond the domestic phase and "prepare for a global world."8

6. I fundamentally disagree with the criticisms of Ewald, "Comparative Jurisprudence (I): What Was It Like to Try a Rat?" 143 U. of Pa. L. Rev. 1889 (1995); an articulated response can be read in Zekoll, "Kant and Comparative Law - Some Reflections on a Reform Effort," 70 Tulane L. Rev. 2719 (1996).

7. Indeed one could argue that in the global world scholarship should mostly be devoted to radically different legal cultures. See Jacques Vanderlinden, Comparer les droits (1995) and the book review by Rodolfo Sacco, 48 Rev. Int'l Droit Comp. 659 (1996).

8. In a recent paper, Mathias Reimann disagrees with the need for a general introduction and actually argues for a demise of it in favor of a general comparative 
The remaining explanations may have more merit. It is difficult to replace academic comparative lawyers with American-trained scholars because of language barriers and the high level of commitment needed to engage in comparative law in the competitive academic environment of the United States. Moreover, due to the provincial attitude widespread in American legal academia, many disciplines dealing with legal problems abroad, including International Law, International Human Rights, International Business Transactions, and International Organizations, are considered perfectly satisfactory, and even attractive, substitutes for comparative law. Their methodology, based as it is on a body of real (positive) law, is much more palatable and understandable for a domestic lawyer than the more demanding concepts of comparative law. It is sufficient to glance at the applications for entry level positions in American universities to see that many more people indicate an interest in these specialties than in comparative law. In the AALS directory of law teachers, the complete listing for comparative law (including Roman Law, Foreign Law and issues of law in developing countries) covers four pages. The "international" list is more than twice as long. One should also consider that a number of people list themselves as "comparative lawyers" simply because they know a foreign language or have spent a couple of weeks participating in a rule of law fostering, American-based program in a foreign country. The actual ratio of professional American comparative law experts to professional International lawyers becomes smaller still. It is consequently little wonder that it is possible to advertise a global law school with a few (if any) comparative law experts. There are simply cheaper and more abundant substitutes available.

Nor is the situation likely to improve because of the globalization of the economy. Indeed, it is quite clear that the only significant meaning of globalization in the law today is Americanization. For reasons that I have explored elsewhere, and certainly for others that are beyond the scope of this paper, American law has become hegemonic in the world at the scholarly level. ${ }^{9}$ This is true also at the teaching level. International LL.M. programs in the United States are often no more than one-year introductory courses to American

approach to the core curricular disciplines. See Reimann, "The End of Comparative Law as an Autonomous Subject," 11 Tul. Eur. \& Civ. L.F. 49, 50 (1996). This kind of argument is commonly used by the enemies of comparative law during faculty recruitment meetings to defeat proposals in favor of the discipline. In Italy, as in the United States, there is always "something more important" than comparative law when resources are being allocated. The argument of the "comparatization" of the basic curricular courses is just too dangerous in the present scenario, because it would allow the appointment of unqualified comparatists to teach basic courses with the vague promise of some future opening in comparative law.

9. See Mattei, "Why the Wind Changed: Intellectual Leadership in Western Law," 42 Am. J. Comp. Law 195 (1994). 
law for foreigners. The customers of these programs come to the United States to study American law, not comparative law, so a number of law schools are able to offer an International LL.M. Program without having comparative law experts on the faculty. And if globalization implies a uniform worldwide law based on the U.S. notion of the Rule of Law, it is easy to see that there will not be much need for familiarity with alternative ideas of law and order, or alternative institutional arrangements in the global world. After all, the job of the comparative law scholar is to explore differences, analogies, analogies hidden behind apparent differences or differences hidden behind apparent analogies. If the differences disappear, the main focus of our discipline disappears as well.

If this were an accurate picture, there would be little room left for optimism. But things are seldom as bad (or as simple) as they seem. Our discipline has already survived the disappearance of one major object of observation - the fall of the socialist legal order. Few were so arrogant as to say that the comparative law scholars would be out of work in the post-socialist world. Indeed, what has been called "transitional jurisprudence" in Central and Eastern Europe is probably one of the most interesting objects of observation for anybody interested in legal and social change today. ${ }^{10}$

If comparative lawyers failed to play an important role in those developments, it may be because the methodology they were able to offer was uninteresting and obsolete. In times of transition, there is little need for black letter analysis or the descriptive approaches utilized by comparative law scholars worldwide. There is a need for institutional engineering based on informed guesses and informed choices between alternative institutional arrangements. ${ }^{11}$ Such choices must take social and economic impacts into account and should be compatible with complex formal and informal institutional backgrounds. ${ }^{12}$ For this reason, a certain type of comparative law professional could be of tremendous help in transitional contexts. These observations are by no means limited to the context of transition and development. Globalization inevitably implies change, a global institutional change affecting most of the legal systems in the world. Globalization can be seen as a fluctuation in the law, a general transition toward a more integrated legal order following the demise of the State and the insurgence of alternative international centers of power. Nevertheless, cultural differences will never completely disappear. In a way, globalization is to general comparative law what the fall of the Berlin wall was for Soviet legal studies. It is a revolution-

10. See Teitel, "Transitional Jurisprudence: The Role of Law in Political Transformation," 106 Yale L.J. 2009 (1997).

11. See generally, Ugo Mattei, Comparative Law and Economics (1997).

12. See Douglass C. North, Institutions, Institutional Change and Economic Performance (1990). 
ary moment which carries with it a great opportunity that we do not want to miss. How can we best equip ourselves for the task?

The future of comparative law and its chance for success in the United States are related to a phenomenon endogenous to the legal profession. Law has a remarkably practical dimension. It is not only scholarship, it is also a practical instrument for managing social conflicts that are handled by professionals in western societies. This practical dimension is not shared by the majority of academic disciplines in the social sciences. ${ }^{13}$ Indeed, no group of professionals practice sociology, anthropology or even economics. To be sure, all social sciences have some practical applications but none comparable to those of law. There seems to be a tradeoff between practical involvement and scholarly excellence. This tradeoff, arguably true also at the individual level, is certainly the case within the legal profession as a whole and, more significantly for us, in legal academics as compared to other branches of social knowledge. In other words, at the individual level, if a legal scholar devotes most of her time to practicing law, it will certainly affect the quantity and probably the quality of her scholarly production. Even a superficial comparison shows that in those legal systems in which legal academics are full-time scholars because a variety of institutional mechanisms discourage academics from legal practice (the U.S. and Germany are prime examples ${ }^{14}$ ), the scholarly output will invariably achieve a dominant position both domestically and abroad. Conversely, because of the simple mechanism of division of labor, well explained in economic theory, the quality and quantity of legal scholarship produced in countries in which academics must practice to make a living is remarkably lower. The same phenomenon becomes apparent when comparing legal scholars with other social scientists. Indeed, it is a fact that lawyers have been and certainly are the most colonized academic community. They have traditionally followed paradigms of research developed in other disciplines (this is most clear if one looks at the philosophical roots of lawyerly discourse). Today, the explosion in the United States and elsewhere of the "law and" approach is only the most visible result of this phenomenon. Lawyers have never been able to participate as peers at the high table of social sciences because their practical worries have influenced their methodology in a way that makes it most uninteresting to scholars in other fields. Interestingly, if one walks into a general bookstore in most countries in the world, one will invariably find rather spare offerings in the law sections compared to those devoted to all the other social sciences. Indeed, most of the ma-

13. The point is developed in Mattei, supra n. 11, at $10-11$.

14. See the comparative data in the symposium, "Selecting Minds," $41 \mathrm{Am}$. J. Comp. L. 351-514 (1992). 
terial produced by lawyers circulates in channels that are segregated from those of general culture.

If there is one group of academic lawyers that has the potential to purge itself of the methodological shortcomings imposed by practical needs, it is the comparative law community. As a scholarly discipline whose primary task is understanding similarities and differences among systems of law governing different societies, ${ }^{15} \mathrm{com}$ parative law has the potential to bring "real" legal issues to the table of the general social science discussion, and to supply a much needed dose of realism to many of them. I have personally strived to bring this contribution to the attention of economists. I believe, however, that many other communities of social scientists are in need of real law injections based not on the contingencies of one particular legal system but on a broader understanding of law as a phenomenon of social organization which is present, with different local characteristics, in all of the world's societies. ${ }^{16}$

Today, there is a resurgence of methodological discussion in the social sciences. Tedious as one may find it, comparative lawyers should seize this opportunity to participate in the debate, emphasizing the advantages that their sophisticated methodology can bring to the scholarly agenda of the new millennium. Comparative law has matured from the common core ${ }^{17}$ approach to legal transplants, ${ }^{18}$ from legal formants, ${ }^{19}$ to the idea of legal traditions as a phenomenon of path dependency, ${ }^{20}$ and on to the notion of the mute dimension of the law. ${ }^{21}$ Comparative legal scholarship has managed to move quite beyond legal positivism, formalism, realism, and black letters. We know how to approach both conscious and unconscious phenomena; the tacit or mute dimension of the law is never neglected. Law will never again be considered a mere aggregate of rules. It is now perceived as a complex relationship of culture, professionalism, power

15. See Sacco, "Legal Formants: A Dynamic Approach to Comparative Law," 39 Am. J. Comp. L. 1349 (1991).

16. See Grande, "L'apporto dell'antropologia alla conoscenza del diritto," 14 Rivista Critica del Diritto Privato 467 (1996).

17. See Formation of Contracts: a Study of The Common Core of Legal Systems (Rudolf B. Schlesinger ed., 1968); for a more recent application see Bussani \& Mattei, "The Common Core Approach to European Private Law," 3 Colum. J. Eur. L. 339 (1997/1998).

18. See Alan Watson, Legal Transplants: An Approach to Comparative Law (1974); Watson's work is discussed, and a bibliography is provided, by Ewald, "Comparative Jurisprudence II: The Logic of Legal Transplants," 43 Am. J. Comp. L. 489 (1995).

19. See Sacco, supra n. 15; Monateri \& Sacco, "Legal Formants," in The New Palgrave Dictionary of Economics and the Law (Peter Newman ed., 1998).

20. Mattei \& Cafaggi, "Comparative Law and Economics" (id.); Mattei, Antoniolli \& Rossato, "Comparative Law and Economics," in Encyclopedia of Law and Economics, (Boudewijn Bouckaert \& Gerrit De Geest eds., 1998).

21. See Sacco, "Mute Law," 43 Am. J. Comp. L. 455 (1995). 
and economics. In other words, the best comparative methodology is capable of managing the staggering complexity of social organization.

In September 1997, a group of sociologists, economists, anthropologists and political scientists met in St. Louis to discuss fundamental problems raised by emerging institutional economics in the context of a trend toward unified social sciences. While no lawyers were invited to participate, many of the papers dealt with topics requiring some legal expertise and most, like much of the work in neoinstitutional economics, were based on some form of comparative study. A conscious effort should be made to integrate comparative legal expertise into the development of a new brand of general basic research in social sciences.

A similar resurgence of methodological interest is also evident in law schools. In a recent issue, the Wisconsin Law Review published a symposium in which the contributors discussed the relationship between law and economics and law and society. ${ }^{22}$ Once again, the comparative law community missed the boat. While a number of the most interesting proposals for common research agendas and approaches included some form of comparative methodology ${ }^{23}$ no comparative law scholar contributed to the symposium. These are opportunities that should not have been missed. The absence of a comparative law scholar from that discussion is even more troublesome because the Wisconsin symposium was premised on a dichotomy between positive and interpretive approaches to legal scholarship that, from a comparative law perspective, makes no sense. ${ }^{24}$ If there is one thing we have learned to recognize from addressing legal problems with a culturally critical and methodologically skeptical approach, it is the culturally dependent nature of every taxonomic scheme, including that between positive and interpretive analysis. Law reflects both aspects and both are perfectly compatible within a framework sophisticated enough to accommodate the complex nature of the law, including institutional arrangements both formal and tacit as well as interpretive strategies to construct them. ${ }^{25}$

Why is it that comparative lawyers have not been invited to participate despite the potential contributions they might offer? I think that in the United States comparative law suffers from a double disadvantage. Among non-lawyers, comparative law is discriminated against because of its subject matter. Social scientists consider law

22. See Symposium "Law and Society \& Law and Economics: Common Ground, Irreconcilable Differences, New Directions," 1997 Wis. L.R. 375.

23. See Komesar, "Exploring the Darkness: Law, Economics and Institutional Choice," 1997 Wis. L. R. 465.

24. See Galanter \& Edwards, "Introduction: The Path of the Law Ands," 1997 Wis. L. R. 375.

25. See Ugo Mattei \& Pier Giuseppe Monateri, Introduzione Breve al Diritto Comparato 39 (1997). 
technical, practical, difficult to understand and therefore useless in interdisciplinary research projects. Because they fail to perceive any difference between "real" and comparative lawyers, they avoid them all. Among lawyers, it seems that comparative law suffers from the underdeveloped methodological awareness that affects it in the United States. While such movements as Law \& Economics, Critical Legal Studies, Feminist Jurisprudence and Critical Race Theory offer path-breaking contributions, most of the important advances in comparative law today occur outside the United States. ${ }^{26}$ While American scholars engaged in these critical approaches and comparativists in Europe have actively engaged in dialogue with their colleagues in the social sciences, American comparative lawyers have, by and large, failed to do so. The most likely explanation, as Duncan Kennedy has observed, ${ }^{27}$ is that all Americans are comparativists to the extent that they consult out-of-state authorities. As is often the case when practical needs override scholarly interest (the rule stare decisis being the most interesting example), no one takes time to study, understand or verbalize the activity of comparing. These activities (comparing American jurisdictions, following legal precedents and so on) become part of what Michael Polanyi calls the tacit knowledge, ${ }^{28}$ the obvious and routine activities that do not commend nor require explanation. $^{29}$ Consequently, a preponderance of the scholarship published in this country by comparative lawyers is methodologically unaware, simply applying the same exercise of comparing one U.S. jurisdiction to another to multinational jurisdictions. The consequences are easy to imagine. American jurisdictions are imbued with common institutional characteristics that are simply absent or poorly developed abroad. Language is one, and perhaps not even the most important, of these aspects. As a result, American comparative lawyers are perceived as informers (and often very biased ones) of what is happening abroad. This information is not particularly valued in this country and will become even less so with the advance of globalization. ${ }^{30}$

In the global world there is a fundamental need for sophisticated comparative scholarship that can be produced only by interdisciplinary efforts involving legal experts in basic research. In the global world the differences between jurisdictions will not disappear, they will simply be more difficult to spot and more in need of being understood and respected.

26. This perception is shared by the leading legal anthropologist. See Laura Nader, Law in Culture and Society iv (1969).

27. See Duncan Kennedy, A Critique of Adjudication (fin de siecle) 78 (1997).

28. See Michael Polanyi, The Tacit Dimension (1967).

29. See Sacco, supra n. 21.

30. See Clifford Geertz, Local Knowledge: Further Essays in Interpretive Anthropology (1983). 
Indeed, the poor prospects for incorporating professional (local) legal knowledge into interdisciplinary research in social sciences creates a great opportunity for comparative law scholars, but it will require tremendous methodological awareness (lacking in American comparative law more than abroad) to seize this opportunity. Such efforts should be aimed at avoiding the dispersal of general comparative law into a variety of unrelated area studies. Comparative lawyers should make the effort to develop approaches that make the increasing complexity of the global world amenable to general comparative analysis. This is a prerequisite to making their knowledge transferable both across jurisdictions and across social sciences. ${ }^{31}$ Whether this awareness will come from the rise of a "Comparative Law and ..." kind of approach, or whether comparative law will be able to become, as Professor Gordley has argued, ${ }^{32}$ the only legitimate arena of legal scholarship is not easy to predict.

While neither methodological awareness nor interdisciplinary efforts will naturally follow globalization, they represent the only chance for survival as well as the key for success of comparative law in the United States.

31. I try to develop these ideas in Mattei, "Three Patterns of Law. Taxonomy and Change in the World's Legal Systems," 45 Am J. Comp. L. 5 (1997).

32. See Gordley, "Comparative Legal Research: Its Function In the Development of Harmonized Law," 43 Am. J. Comp. L. 555 (1995). 